\title{
BIRDS
}

\section{ERICKSON STUDY AREA: DUCK BREEDING POPULATIONS AND HABITAT, THEN (1970-72) AND NOW (2008-13).}

GORD HAMMELL, P.O.Box 37, Erickson, MB, R0J0P0; email: hammell@inetlinkwireless.ca

\section{INTRODUCTION}

Parklands in Manitoba are a dynamic environment characterized by irregularlyoccurring wet and dry years which in turn, affect the number of wetlands available to waterfowl. ${ }^{1,2,3}$ Wetlands are critical for waterfowl reproduction and the abundance and degree of permanency of these wetlands is one factor that determines the size of duck breeding populations. ${ }^{2,3}$ During the late 1980's and early 1990's, a dry period existed across southern Manitoba which reduced the number of wetlands available to ducks and consequently, breeding populations declined from highs in the 1970's. ${ }^{3}$ Heavier precipitation returned in the late 1990's, continuing through the 2000's, filling wetlands in southern Manitoba and in conjunction with enhanced conservation efforts, numbers of most waterfowl species have returned to levels at or above those seen in the early seventies and at or above goals set out by the North American Waterfowl Management Plan. ${ }^{3}$
In 1986, the North American Waterfowl Management Plan was formulated by the U.S. and Canadian governments to address declining waterfowl populations and to (1) set population goals for those species that breed in the prairie, parkland and boreal areas and (2) promote and fund management practices that enhance waterfowl production. ${ }^{4}$

One species whose continental population has been declining since the 1980's and that did not recover after the midcontinent drought is the lesser scaup (Aythya affinis, hereafter scaup). ${ }^{3,5} \quad$ Scaup breed from the Dakotas to Alaska ${ }^{6}$ and the parkland scaup population in southern Manitoba has been intensively studied near Erickson, Manitoba, Canada (50 $30^{\prime} \mathrm{N}$, $\left.99^{\circ} 55^{\prime} \mathrm{W}\right)$ since the 1950 's. ${ }^{7-12}$ I studied scaup from 1970-72 within this site and have farmed in the area since, allowing me an opportunity to observe and record changes in the area over the past forty-three years. Since this site 
has had such a rich waterfowl research history and little current comparative data exist, in 2008, I decided to revisit my study area to record (1) current duck breeding population levels (with primary focus on scaup), and (2) changes to habitat and populations of some other species that might influence duck reproductive parameters. I compared the results to those of forty years previous. Managers need current data on abundance and reproductive performance of species, but also accurate comparative information from the past to formulate conservation policies.

\section{STUDY AREA AND METHODS}

My block study area (BSA) is situated $\sim 3.4 \mathrm{~km}$ southeast of the town of Erickson and comprises 680 ha of rolling parkland habitat (Fig 1). The area has been well described in previous studies, all of which occurred on or near the BSA. ${ }^{10,12,13}$ To record breeding populations of waterfowl and other species, one or two observers walked a fixed route between 600 and $1300 \mathrm{hrs}$ at $\sim$ weekly intervals from early May to late June, 197072 and from mid-May to mid-June, 2008-13 (5-6 annual surveys). In 1970 , only that part of the BSA including most of the permanent and semi-permanent wetlands (350 ha, $70 \%$ of total wetlands) was surveyed so the actual total number of breeding ducks are most likely higher than those recorded. However, subsequent observations over the years of those wetlands not observed in 1970 suggest that recorded 1970 diving duck numbers are close to those that would have occurred in the study area. Dabbling duck numbers are biased lower for that year. For dabbling duck species, breeding pairs were recorded following the protocol of Dzubin. ${ }^{14}$ For diving duck species, observed pairs plus single males on isolated ponds were added for total pair count. Non-paired diver males tended to congregate on larger lakes and in most cases, single males observed on larger lakes were considered not to represent pairs. For divers, emphasis was placed on surveys conducted during the pre-egg laying and early laying periods to avoid the bias of these non-paired males being counted as representing pairs; I approximated timing of egg laying by backdating embryo age (1970-72) or by backdating from date of earliest brood appearance and by observed pair behaviours (2008-13). However, for the recent study period, Buffleheads (Bucephala albeola), a species of diving duck, began laying earlier than the date of first survey and some single males on larger lakes were, depending on behaviour and location, considered to 


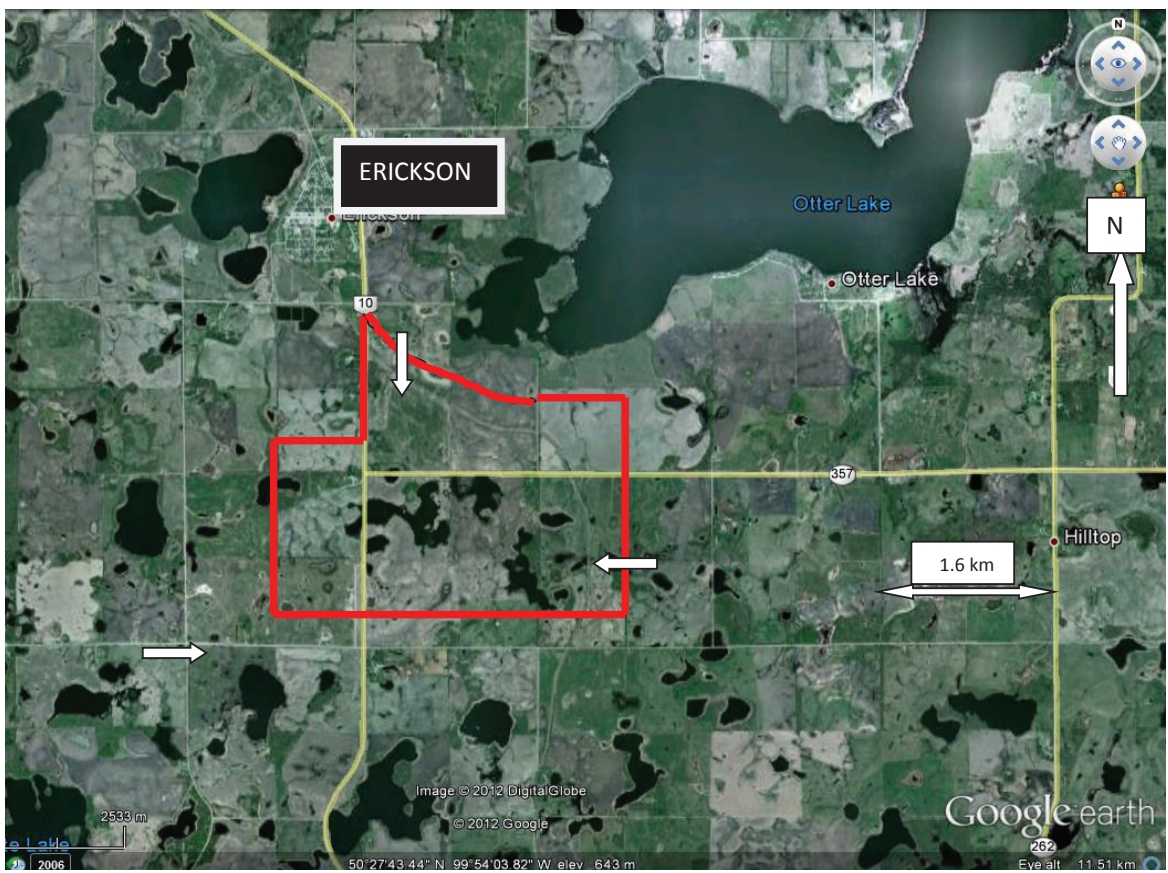

Figure 1. Location of 680 ha Erickson study area in southwestern Manitoba. Heavy line marks boundary. Arrows indicate areas of dense nesting cover on or adjacent to study area. Water conditions are as of May, 2011.

represent pairs. For all species, I averaged the results of surveys conducted during survey periods as described above and by Dzubin $^{14}$ and I compared the results between 1970-72 and 2008-13. As sample sizes are small and distribution of variables is unknown, I rank-transformed the values for each species in each period and performed a Wilcoxon rank-sum test via a parametric t-test to determine the significance of each comparison. ${ }^{15}$

To document habitat change,
I gathered quantitative and qualitative data on some of those factors that might affect waterfowl production. This analysis was not extensive or in-depth and represents an overview only. To describe wetlands, I used the classification criteria of Stewart and Kantrud..$^{16}$ To compare water conditions on the study area between the time periods 1970-72 and 2008-13, I examined aerial photos and Google Planimeter to determine number and size of ponds and upland characteristics (\% area cultivated, \% haylands, 
etc.). Also, I averaged May pond numbers (an indicator of waterfowl habitat quality) from annual waterfowl survey segments $(400 \mathrm{~m}$ $x 29 \mathrm{~km}$ ) flown along fixed transect lines near Erickson (stratum 40: transect 6 , segments 3 and 4). ${ }^{17}$ To gather information on the predator community in recent times, I established ten scent stations located < five meters from water's edge and $>200 \mathrm{~m}$ apart near nine permanent or semi-permanent ponds. ${ }^{18} \mathrm{~A}$ plastic sheet $1 \mathrm{~m}$ in diameter, was covered in seven-ten $\mathrm{cm}$ of fine soil that was raked smooth with a comb and lightly watered. One half to one $\mathrm{ml}$ of commercial scent (Original Hoffman Lure Making Ingredients: Fish Juice; www. cabelas.ca) was applied to the centre of the smoothed soil prior to each exposure night. Stations were prepared after 1800 hours to reduce surface desiccation and checked for tracks ${ }^{19}$ on two successive nights, five times (3 in 2009; 2 in 2010) during a part of the scaup nesting period (26 June12 Aug). Relative abundances were determined from the number of stations visited by a predator species each night divided by the number of stations. Mean relative abundance was calculated for each species for the entire test period (10 exposure nights) and these means were compared to proportions of depredated lesser scaup nests attributed to various predators frequenting this wetland zone during 1970-72 ${ }^{9}$ (unpubl. data). This comparison does not account for changes in the relative abundance of each predator species over time (data sets for each time period were obtained by different methodology) but provides a "rough" estimate of activity immediately around permanent wetlands during each time period. The nature of the predator community and abundance on drier sites was not assessed for either time period.

\section{RESULTS and DISCUSSION}

Wetland and upland conditions

Wetland water levels were high in all study years but higher in the 2000's. Water levels began to retreat in late summer of 2011 and with little spring run-off, continued to decline through 2012. Permanent ponds remained high throughout 2012 because of record flooding in 2010- 2011, but most semi-permanent and all seasonal wetlands were dry by fall, 2012. In 2013, water conditions improved and emergent vegetation flourished. Wetland area increased from $12 \%$ in the 1970 's to $14 \%$ in 2011 , the wettest year (Table 1). The average of the May pond numbers recorded on the annual survey for segment 3 and 4 , transect 6 , was above the 


\begin{tabular}{|c|c|c|}
\hline Use (\%) & $1970-72$ & $2008-13$ \\
\hline cultivated & 46 & 39 \\
\hline pasture $^{a}$ & 14 & 13 \\
\hline hay & 20 & 24 \\
\hline bush & 5 & 6 \\
\hline wetland & 12 & 14 \\
\hline other ${ }^{b}$ & 3 & 4 \\
\hline
\end{tabular}

long-term average for all years except 2013. Approximately 12 $\%$ of BSA wetlands $(n=160$ in 1970-'72) were drained, partially drained or filled between 1970 and 2013 (i.e.: 2 small dugouts and 17 seasonal ponds; $\sim 6$ ha total); this relatively small loss compares to $\sim 70 \%$ wetlands degraded or lost due to drainage (19682005 ) in the Broughton's Creek watershed, an area considered to be representative of southwestern Manitoba land use and wetland loss trends. ${ }^{20}$

Areas of upland used for agricultural purposes were similar in composition and extent for both periods, but one block of the pastureland (ca $50 \mathrm{ha}$ ) and one block of hayland (ca 55 ha) are currently, idle, providing excellent dense nesting cover (Fig. 1). The railway track and right-of-way that traversed the BSA in the 1970's has since been converted to a walking path (Trans-Canada Trail), providing a ribbon of habitat for plants and animals. Also, a 45 ha block of dense upland cover (Ducks Unlimited Canada) was established during the 1990's adjacent to the southwest corner of the BSA.

Between study periods, a major shift occurred in cereal and oilseed cropping practices in southern Manitoba (and on the BSA) from rotating summerfallow to continuous cropping, employing minimum or no-till methods. Concurrently, a shift in pasture management techniques also occurred involving the increased use of rotational grazing. Pastures were divided by fencing to create more numerous smaller paddocks and cattle were rotated between 


\begin{tabular}{|c|c|c|}
\hline $\begin{array}{l}\text { TABLE 2. Frequenc } \\
\text { ten scent stations }(2 \\
\text { proportion of depred } \\
\text { attributed to various } \\
\text { near Erickson, Mani }\end{array}$ & $\begin{array}{l}\text { of preda } \\
09-10) \text { ar } \\
\text { ted scaur } \\
\text { redators } \\
\text { ba. }\end{array}$ & $\begin{array}{l}\text { acks at } \\
\text { ts } \\
-72)\end{array}$ \\
\hline Species & Tracks ${ }^{a}$ & Nests $^{b}$ \\
\hline Racoon & $\begin{array}{l}0.23 \\
(.05)\end{array}$ & 0.47 \\
\hline & 0.02 & \\
\hline Skunk & $(.01)$ & 0.20 \\
\hline Coyote/fox & $\begin{array}{l}0.05 \\
(.02)\end{array}$ & 0.13 \\
\hline magpie/Crow/raven & $\begin{array}{l}0.01 \\
(.01)\end{array}$ & 0.04 \\
\hline Mink/weasel & $\begin{array}{l}0.13 \\
(.03)\end{array}$ & 0.07 \\
\hline & 0.01 & \\
\hline Black Bear & $(.01)$ & 0 \\
\hline unknown & $\begin{array}{l}0.03 \\
(.02)\end{array}$ & 0.09 \\
\hline a mean $(\mathrm{se})$ & & \\
\hline
\end{tabular}

these paddocks. As a result, pastures are now idle for longer periods of time, vegetation (and ground nesting cover) grows undisturbed between grazing periods, and grazing residue height is taller providing presumably improved habitat for ground nesting bird species and small mammal populations. Small mammals (Microtus, Peromyscus, Clethrionomys, Poliocitellus spp) provide an alternative food source for some waterfowl predators and may also depredate waterfowl nests. ${ }^{21,22}$

\section{Predator populations}

The species, both avian and mammal, that prey on waterfowl nests are numerous and well documented. ${ }^{22}$ Active and abandoned farmyards are known to be used by predators and might influence the nearby predator community. pers. obs.,23,24 These farmyards were present in both periods on the BSA (1970's: 5 abandoned, 7 occupied; 2000's: 4 abandoned, 5 occupied, 1 commercial). Data from scent stations during 2009-10 and proportions of depredated lesser scaup nests attributed to predators during 1970-'72 suggest that the predator community now 
around wetland edge is similar (but not the same) in species makeup. Racoons (Procyon lotor) predominated in both time periods, being the most frequent scent station visitor and most significant predator of scaup nests, at least in the 1970's period (Table 2). Other predators recorded with less frequency in 1970-72 and 2009-10 were mink (Neovison vison), skunk (Mephitis mephitis), coyote (Canis latrans), fox (Canis vulpes), crow (Corvus brachyrhynchos), and magpie (Pica hudsonia); black bear (Ursus americana) was only recorded in 2009. Although these two data sets invite comparison, such a comparison has limited value because the two data sets were obtained with different methodology. I conclude with confidence however, that the racoon, a recently arrived predator in the Erickson area (mid-1960's) ${ }^{25}$ is still a significant predator around wetland edges.

The number of waterfowl predator species has expanded since 1970's. There is now presence of black bear, fisher (Martes pennanti), martin ( $M$. americana) and summertime (breeding) ravens (Corvus corax) in the area. The effects on the local duck populations of these additional potential waterfowl predator are unknown. Bear numbers have increased since the early 1970's and sign of their activity on the study area was frequently seen in recent years (pers obs., local outfitters, Table 2). Fisher and martin were reintroduced to Riding Mountain National Park (RMNP), situated $\sim 18 \mathrm{~km}$ north of the BSA between 1991 and 1995 and have become widespread (RMNP data) and have been reported in the Erickson area (local residents and trapper obs.). Interestingly, anecdotal local evidence suggests that fishers are significant predators of domestic cats (Felis catus) which are known predators of birds, including ducks (pers. obs). Ravens were rare or absent during the summer in the early 1970's but are common now and are known to nest across southwest Manitoba ${ }^{26}$ (pers.comm. C. Cuthbert, Ducks Unlimited). Ravens are known predators of waterfowl nests. ${ }^{27}$

\section{Other animal species}

Populations of several other species associated with wetlands have increased significantly since the early 1970's. The return of beaver (Castor canadensis) and Canada geese (B. C. maxima) in the early 1980's was dramatic. The presence of old beaver dams and runs on the landscape around the Erickson area, however, suggests there was a robust population sometime in the past. 
Beavers significantly altered most permanent and semi- permanent ponds in the last 30 years and created new impoundments wherever they found running water and a food source. Water levels on these existing and new wetlands were dramatically altered by beavers building dams and people removing them to alleviate flooding. In some instances, these level fluctuations may have been detrimental to floating or pondedge waterfowl nests. Trees and shrubs surrounding wetlands were flooded and felled by beavers, altering the habitat and making some small willow-dominated (Salix spp.) wetlands larger and thus accessible to waterfowl. In fall, 2011-2013, beavers occupied 5-7 wetlands on the BSA.

Canada geese are now abundant breeders in southwestern Manitoba. They were absent, at least around Erickson, in the early 1970's. Large gatherings of Canada goose adults and gosling (e.g.: 100 individuals; $75 \%$ goslings in 2008) were recorded on the $B S A$ in most years during 2008-'13. Goose eggs and goslings likely provide an additional food source for some predators. Over the forty years, another obvious change in the avian fauna occurred, that being a large increase in breeding Red-necked grebes
(Podiceps grisegena) on the BSA (1970-72: 0-2 birds/year ; 2008-13: 28-34) and in southern Manitoba in general; these grebes were uncommon in the early 1970's. ${ }^{28}$ In contrast, Horned Grebes (Podiceps auritus), which were abundant on the BSA (1970-72: 5-21 birds/year) and elsewhere in the early 1970's, ${ }^{29}$ have decreased in southwestern Manitoba and there were no breeding pairs in 2010-13 on the BSA (2008-13: 0-2 birds/ year). Red-necked grebes are fiercely territorial and can displace waterfowl from territories. ${ }^{30,31}$

An additional environmental parameter, the presence of fish in wetlands, may have deleterious effects on food quantity for some waterfowl species (e.g.scaup) either by direct competition or through disturbance to the aquatic environment by their feeding activities. ${ }^{32}$ At Erickson, fish populations exist in some permanent and semi-permanent wetlands and may affect waterfowl production but there are no local data. Smaller ponds may contain, depending on location, depth, and water conditions, fathead minnow (Pimephales promelas), and/or brook stickleback (Culaea inconstans). Larger, deeper lakes may contain, in addition to fathead and stickleback, populations of northern pike (Esox lucius), 
yellow perch (Perca flavescens), and white sucker (Catostomus commersonii). ${ }^{33}$ On the BSA, the type and size of any native fish populations are unknown and may be absent as most of the larger bodies of water are isolated and do not have drains directly connecting them to lakes with permanent fish populations. I have seen no evidence of native fish species in these BSA lakes but they may be there in some years. However, periodically, rainbow trout (Oncorhynchus mykiss) have been stocked by local landowners in some of the lakes on and off of the BSA. These introduced fish are released in the spring and netted in the fall. In most cases, reduced oxygen levels during winter prevent trout from surviving. The Federal Department of Fisheries undertook rainbow trout research at Erickson in 1968 to investigate the feasibility of fish farming using local wetlands and a large number of lakes at that time had trout introduced (e.g: 12 lakes in 1970; 30-40 lakes [350,000 fish] in 1972 ). ${ }^{33}$ The research found large-scale fish-farming to be economically unfeasible and the research ended in 1982 but the practice is continued by some landowners at a much reduced level. On the BSA from 19782010 , trout were stocked in one or two lakes each year; none were stocked in 2011-2013. In the $373 \mathrm{~km}^{2}$ Rural Municipality of Clanwilliam, in which the BSA is located, only 3 lakes contained trout in 2011.33 Undoubtedly at Erickson, trout and other fish species compete with waterfowl for aquatic invertebrates but the effect is unknown.

\section{Invasive plant species}

Two readily noticeable changes to the Erickson area wetland plant community over the last several decades have been the increasing occurrence of reed canary grass (Phalaris arundinacea) and hybrid cattail (Typha x glauca). Reed canary grass is a robust, sodforming perennial grass that grows from $50-150 \mathrm{~cm}$ tall. It is usually associated with moist soils where it forms dense monotypic, persistent stands. It colonizes readily by root or seed and may exclude or displace other plant species. There were few stands of this grass near Erickson in the early 1970's and I believe that there were none on the BSA. During the 1960's-'80's, some landowners (including the author) sowed the species in and around wet areas for cattle forage but its unpalatability as hay and its aggressive nature means there are few plantings now. The resulting spread of this plant on some farmsteads and the altered vegetative community around wetlands may affect waterfowl. 
TABLE 3. Estimated number of breeding pairs of ducks on the 680 ha study area near Erickson, Manitoba, 19701-72 and 2008-13.

\begin{tabular}{|c|c|c|c|c|c|c|c|c|c|}
\hline \multirow[t]{2}{*}{ Species } & \multicolumn{9}{|c|}{ Year } \\
\hline & 1970 & 1971 & 1972 & 2008 & 2009 & 2010 & 2011 & 2012 & 201: \\
\hline Lesser Scaup* & 22 & 19 & 23 & 2 & 5 & 4 & 3 & 3 & 3 \\
\hline Ring-necked ${ }^{*}$ & 0 & 0 & 1 & 9 & 22 & 14 & 13 & 13 & 10 \\
\hline Bufflehead ${ }^{*}$ & 1 & 0 & 1 & 12 & 15 & 17 & 16 & 16 & 18 \\
\hline Goldeneye & 1 & 1 & 1 & 0 & 0 & 0 & 0 & 1 & 2 \\
\hline Canvasback & 7 & 4 & 5 & 3 & 1 & 5 & 4 & 3 & 6 \\
\hline Redhead & 2 & 3 & 1 & 8 & 2 & 1 & 4 & 4 & 4 \\
\hline $\begin{array}{l}\text { Ruddy } \\
\text { Hooded }\end{array}$ & 4 & 2 & 4 & 7 & $\begin{array}{l}8 \\
0\end{array}$ & 2 & 2 & 0 & 0 \\
\hline Merganser & 0 & 0 & 0 & 0 & 0 & 0 & 0 & 0 & 0 \\
\hline Mallard & 11 & 15 & 18 & 18 & 16 & 23 & 12 & 23 & 19 \\
\hline Shoveler ${ }^{*}$ & 1 & 1 & 2 & 5 & 5 & 4 & 4 & 6 & 7 \\
\hline Gadwall & 6 & 4 & 1 & 4 & 5 & 4 & 3 & 5 & 3 \\
\hline $\begin{array}{l}\text { Blue-winged Teal } \\
\text { Green-winged }\end{array}$ & 11 & 13 & 15 & 20 & 20 & 20 & 22 & 26 & 15 \\
\hline Teal & 2 & 2 & 3 & 1 & 5 & 2 & 3 & 5 & 4 \\
\hline $\begin{array}{l}\text { Northern Pintail } \\
\text { American }\end{array}$ & 3 & 7 & 7 & 0 & 0 & 0 & 0 & 0 & 0 \\
\hline Widgeon ${ }^{*}$ & 3 & 5 & 2 & 0 & 1 & 0 & 0 & 0 & 0 \\
\hline Wood Duck & 0 & 0 & 0 & 0 & 1 & 0 & 0 & 1 & 0 \\
\hline Total & 74 & 76 & 84 & 89 & 106 & 96 & 86 & 106 & 91 \\
\hline
\end{tabular}

1350 ha censused in 1970; see Hammell 1973

"denotes significant difference $(p<0.05)$ in pair counts between periods

However, reed canary grass has the study area within the last 10not been planted in or around the BSA and only a few scattered small patches occur in the area.

Native cattail (Typha latifolia) was the only emergent Typha species around Erickson in the 1970's. A new species, thought to be predominately the hybrid (Typha $x$ glauca) has invaded southwestern Manitoba ( $\mathrm{J}$. Wasko, Univ. of Manitoba, pers. comm.). The new species is a hybrid between $T$. latifolia and $T$. angustifolia and has occurred in

15 years. On the BSA, obvious (Typha $x$ glauca) patches occur and grow $\sim 1 \mathrm{~m}$ above the native species. The hybrid can overtake native stands and grows in deeper water (J Wasko) potentially reducing areas of open water, eliminating waterfowl habitat. On the BSA, one permanent wetland has extensive stands ( $>50 \%$ ) of the new species, another has a few scattered stands but the other wetlands have no obvious clumps. Generally, across the Erickson area, the degree of 
infestation is minimal at present but is increasing; T. latifolia still is the predominant or only cattail species in most wetlands.

\section{Duck breeding population change}

Total numbers of pairs counted on the BSA during 2008-13 were greater in all years than those counted during 1970-72 (Table $3)$. Abundance of breeding pairs of some species changed dramatically and consistently between the two study periods. Scaup, formerly the most common species on the $\mathrm{BSA}^{8,9}$, have become one of the least common. Ring-necked duck (Athya collaris) and bufflehead have become much more abundant after being uncommon in the early 1970's. Blue-winged teal (Anas discors) and northern shoveler ( $A$. clypeata) have increased also as they have in other areas. ${ }^{3}$ Mallard (A. platyrhynchos) breeding pair numbers are similar or increased. American widgeon ( $A$. americana) and northern pintail ( $A$. acuta), which were recorded in the 1970's but whose continental populations have been below long-term average in recent years ${ }^{3}$ have virtually disappeared from the BSA. Goldeneye (Bucephala clangula) were, for most years in both periods, not present. Wood duck (Aix sponsa) and hooded merganser (Lophodytes cucullatus) pairs and broods were not recorded during 197072 but are more frequent now. The numbers of other duck species including canvasback (Athya valisinaria), redhead (A.americana), ruddy (Oxyura jamaicencis), gadwall (Anas strepera), and green-winged teal (A. crecca)], were small and/or variable with no significant trend.

Possible reasons for the decline in continental scaup numbers include changes to food resources in wintering and migration habitats, ${ }^{34,35}$ chemical contaminate exposure, ${ }^{6,36-39}$ climate changes affecting boreal forest wetlands, ${ }^{5,40}$ lower female survival, ${ }^{5}$ and fewer immature birds relative to adults in human harvests (declining age ratio): ${ }^{5}$ however, as yet, no clear explanation for the decline has been determined. Ringnecked and bufflehead ducks, whose populations in southern Manitoba have been low in the past, ${ }^{2}$ have, on the BSA and more widely in the Erickson parkland area, increased dramatically $(\mathrm{GH}$, unpubl. data)..$^{41}$ The return of the beaver and the subsequent alteration of wetlands occurred concomitantly with these ringnecked and bufflehead breeding population changes. As well, the recent increased sightings of wood duck and hooded merganser pairs and broods in the Erickson area have occurred mainly in wetlands 
altered by beavers (pers. obs.). Wood duck, merganser and bufflehead are tree cavity-nesting species and may be responding positively to the presence of beaver ponds, which often provide numerous dead trees around the periphery. Dead trees contain numerous cavities and may be used as nesting sites by these ducks. Only a few $(<10)$ artificial nest boxes for cavity-nesting ducks have been erected in the Erickson area (none on the BSA) and most have not been regularly maintained.

Reasons for the continental decline in American widgeon populations are unclear. ${ }^{42}$ For northern pintails, the landscape scale change from use of summerfallow to continuous cropping has denied females quality nesting sites. ${ }^{43}$ In the past, stubble fields slated for tillage later in the season (summerfallow) provided good nesting sites for early-nesting pintails. Now, nests in continuously-cropped stubble fields are usually destroyed by the seed drill before they have a chance to hatch.

\section{CONCLUSIONS}

In such a dynamic environment as the Manitoba parklands, it is not surprising that both plant and animal populations would experience temporal and spatial change. I do not know if the degrees and types of change observed on the BSA are the same for all areas of southwestern Manitoba. However, the trends I report are representative of changes in the Erickson area.

The BSA, relative to other areas in southwestern Manitoba, has not suffered extensive habitat degradation. As a result, the total number of breeding ducks on the BSA, 2008-2013, has been maintained or increased over the last 40 years. These results provide evidence that duck numbers can be maintained over time provided that suitable breeding habitat has not been seriously degraded and that environmental factors operating off of the breeding grounds have not negatively affected these populations.

The reappearance of beaver in the early 1980's in the Erickson area has had a major affect on wetlands. For waterfowl, beavers have been beneficial in that they have helped to retain water on the watershed by flooding existing wetlands and by creating new ones. However, landowners use machinery to remove dams and ditches were deepened and wetlands were lost. Accordingly, the net result for waterfowl of the return of the beaver in the local area is uncertain. 
Unfortunately, unregulated draining of wetlands is an ongoing reality across much of southern Manitoba and was especially prevalent during the dry falls of 2011 and 2012. Wetlands provide many societal benefits, including wildlife habitat, downstream flood protection, improvements to water quality and carbon sequestration. ${ }^{20,44,45}$ To realize these societal benefits, wetlands must be retained through programs that encourage land owners to hold water in the upper watershed. Presently, much of the BSA still provides these benefits and it was a rewarding experience to walk the paths that I took 43 years ago and still see wetlands and wildlife in abundance.

\section{ACKNOWLEDGEMENTS}

Dr. E. D. Bailey, and the other members of my University of Guelph committee, Drs. R. J. Brooks, D. H. Pengelly, and R. E. Walker offered guidance and advice. Their assistance during my student years was much appreciated. I thank the landowners and others around Erickson for their hospitality and permission to access their lands. I also thank those who provided help in the field, especially $\mathrm{G}$. Curry, R. Beaver, J. Jefferson and $\mathrm{H}$. Pengelly. Funds for the 1970's study were provided by

72 (3) September 2014 the National Research Council of Canada, Delta Waterfowl Research Station, University of Guelph and Canadian National Sportsman's Show.

I acknowledge the recent help of I. Glass and L. Armstrong (Ducks Unlimited Canada, Oak Hammock Marsh, MB.) and the library staff at Brandon University for allowing me to conduct a literature review using their resources. M. Hammell, Blue Jay editors and an anonymous reviewer provided helpful comments to improve earlier drafts of this manuscript. Most importantly, I thank Marg for her support.

1. Woo MK (1992) Impacts of climate variability and change on Canadian wetlands. Canadian Water Resources Journal 17(1):63-69.

2. Trauger DL, Stoudt JH (1978) Trends in waterfowl populations and habitats on study areas in Canadian parklands. Transactions North American Wildlife and Natural Resources Conference 43:187-205.

3. Fish and Wildlife Service (2013) Waterfowl population status, 2013. U.S. Department of the Interior, Washington, DC USA.

4. What is NAWMP? www.nawmp. ca/eng/part2 e.html 
5. Afton AD, Anderson MG (2001) Declining scaup populations: a retrospective analysis of longterm population and harvest survey data. Journal of Wildlife Management 65:781-796.

6. Austin JE, Custer CM, Afton AD (1998) Lesser scaup (Aythya affinis). In A. A. Pool and F. Gill, editors. The Birds of North America, Number 338. The American Ornithologists Union, Washington, C. 32pp.

7. Kiel WH (1949) Waterfowl productivity in the Newdale -Erickson District of Manitoba.

Pp. 76-81 in Waterfowl populations and breeding conditions - summer 1949. United States Fish and Wildlife Service Special Scientific Report Wildlife No 2. Washington, DC.

8. Rogers JP (1964) Effect of drought on reproduction of the Lesser Scaup. Journal of Wildlife Management 28:213-222.

9. Hammell GS (1973) The ecology of the lesser scaup (Aythya affinis Eyton) in southwestern Manitoba. M.S. Thesis, Univ. Guelph, Ont. $156 p p$.

10. Afton AD (1984) Influence of age and time on reproductive performance of female lesser scaup. Auk 101:255-265.
11. Austin JE, Fredrickson LH (1987) Body and organ mass and body composition of postbreeding lesser scaup. Auk 104:694-699.

12. Koons DN, Rotella JJ (2003b) Have lesser scaup, Aythya affinis, reproductive rates declined in parkland Manitoba? Canadian Field Naturalist 117(4):582-588.

13. Sunde LA, Barica J (1975) Geography and lake morphometry of the aquatic study area in the Erickson-Elphinstone district of southwestern Manitoba. Winnipeg, Manitoba. Environment Canada Fisheries Marine Service Technical Report No. 510.

14. Dzubin A (1969) Assessing breeding populations of ducks by ground counts. Pages 178-230 in Saskatoon Wetlands Seminar. Canadian Wildlife Service Report Series Number 6.

15. McDonald JH (2009) Handbook of Biological Statistics ( $2^{\text {nd }}$ ed.). Sparky House Publishing Baltimore, Maryland.

16. Stewart RE, Kantrud HA (1971) Classification of natural ponds and lakes in the glaciated prairie region. U.S. Fish and Wildlife Service Resource Publication 92, Washington, DC, USA. 
17. United States Fish and Wildlife

Service. Waterfowl Breeding Populations and Habitat Survey Segment Count Data. http:// $\mathrm{mbdcapps.fws.gov/mbdc/}$ databases/mas/dispr_segcnt.asp

18. Roughton RD, Sweeney MW (1982) Refinements in scent station methodology for assessing trends in carnivore populations. Journal of Wildlife Management 46:217-229.

19. Murie, OJ (1974) A field guide to animal tracks. (Peterson Field Guide Series 9)

20. Ducks Unlimited Canada. www.ducks.ca/.../projects/ broughtons/pdf/broughtonsfactsheet.pdf

21. Brook RW, PasitschniakArts M, Howerter DW, Messier $F$ (2008) Influence of rodent abundance on nesting success of prairie waterfowl. Canadian Journal of Zoology 86:497-50.

22. Sargeant $A B$, Savoda $M A$, Greenwood RJ (1998) Interpreting evidence of depredation of duck nests in the prairie pothole region. United States Geological Survey, Northern Prairie Wildlife Research Center, Jamestown, ND and Ducks Unlimited, Inc., Memphis, TN. 72pp.

72 (3) September 2014
23. Fritzell EK (1978) Habitat use by prairie raccoons during the waterfowl breeding season. Journal of Wildlife Management 42:118-127.

24. Lariviere S, Messier F (1998) Denning ecology of the striped skunk in the Canadian Prairies: Implications for waterfowl nest predation. Journal of Applied Ecology.35(2):207-213.

25. Hammell GS (2011) Lesser scaup and raccoons: are there links in southwestern Manitoba? Blue Jay 69(2):54-69.

26. Carey B et al. (2006) Finding birds in southern Manitoba. Manitoba and Brandon Naturalists Societies, Co-publishers.

27. Fournier MA, Hines JE (2001) Breeding ecology of sympatric greater and lesser scaup

(Aythya marila and $A$. affinis) in the subarctic Northwest Territories. Arctic 54(4): 444-456.

28. Trends from the Breeding Bird Survey in Canada: Rednecked Grebe. Migratory Birds Conservation Monitoring and Reporting. Canadian Wildlife Service, Environment Canada, Ottawa.www.cwsscf. ec.gc.ca/mgbc/trends/index. cfm?lang=e\&go=info.birdSumm aryProvince \&provid=5\&species id=6110 http:// 
29. Ferguson RS, Sealy SG (1983) Breeding ecology of the horned grebe (Podiceps auritus) in southwestern Manitoba. Canadian Field Naturalist 97(4): 401-408.

30. Garner LA (1991) Intra- and interspecific aggression by rednecked grebes. Ms thesis, North Dakota State University, Fargo, ND.

31. Stout BE, Nuechterlein GL (1991) Red-necked Grebe (Podiceps grisegena). In The Birds of North America, No.465 (A Poole, F Gill, eds) The Birds of North America, Inc. Philadelphia, PA.

32. Anteau MJ, Afton AD, Anteau ACE, Moser EB (2011) Fish and land use influence Gammarus lacustris and Hyalella azteca (Amphipoda) densities in large wetlands across the upper Midwest. Hydrobiologia 664:6980.

33. Personnel communication, G. Curry, J. Whitaker, former Federal Department of Fisheries personnel.

34. Anteau MJ, Afton AD (2008) Diets of lesser scaup during spring migration throughout the Upper-Midwest are consistent with the spring condition hypothesis. Waterbirds 31:97-106.
35. Anteau MJ, Afton AD (2009) Lipid reserves of lesser scaup migrating across a large landscape are consistent with the "spring condition" hypothesis. Auk 126:873-883.

36. Custer CM, Custer TW, Anteau MJ, Afton AD, Wooton DE (2003) Trace elements in lesser Scaup (Aythya affinis) from the Mississippi flyway. Ecotoxicology 12: 47-54.

37. Anteau MJ, Afton AD, Custer CM, Custer TW (2007) Relationships of cadmium, mercury, and selenium with nutrient reserves of female lesser scaup (Aythya affinis) during winter and spring migration. Environmental Toxicology and Chemistry 26: 515-520.

38. DeVink J-M, Clark RG, Slattery SM, Scheuhammer TM (2008a) Effects of dietary selenium on reproduction and body mass of captive lesser scaup. Environmental Toxicology and Chemistry 27: 471-477.

39. DeVink J-M, Clark RG, Slattery SM, Wayland M (2008b) Is selenium affecting body condition and reproduction in boreal breeding scaup, scoters, and ringnecked ducks? Environmental Pollution 152:116-122. 
40. Drever MC, Clark RG, Derksen C, Slattery SM, Toose P, Nudds TD (2012) Population vulnerability to climate change linked to timing of breeding in boreal ducks. Global Change Biology 18(2):480-492.

41. Koons DN, Rotella JJ (2003a) Comparative nesting success of sympatric lesser scaup and ring-necked ducks. Journal of Field Ornithology 74:222-229.

42. Howerter D (2007) North Carolina study tracts birds in Manitoba. The Flyway Newsletter, Ducks Unlimited Canada. Vol: 28(4).
43. Ducks Unlimited Canada. www.ducks.ca/conserve/ programs/pintail/pdf/pinfacts.pdf

44. Yang WX, Liu WY, Gabor S, Boychuk L, Badiou P (2010) Simulated environmental effects of wetland restoration scenarios in a typical Canadian prairie watershed. Wetlands Ecology and Management 18(3):269-279.

45. Blackwell MSA, Pilgrim ES (2011) Ecosystem services delivered by small-scale wetlands. Hydrological Sciences Journal 56(8):1467-1484.

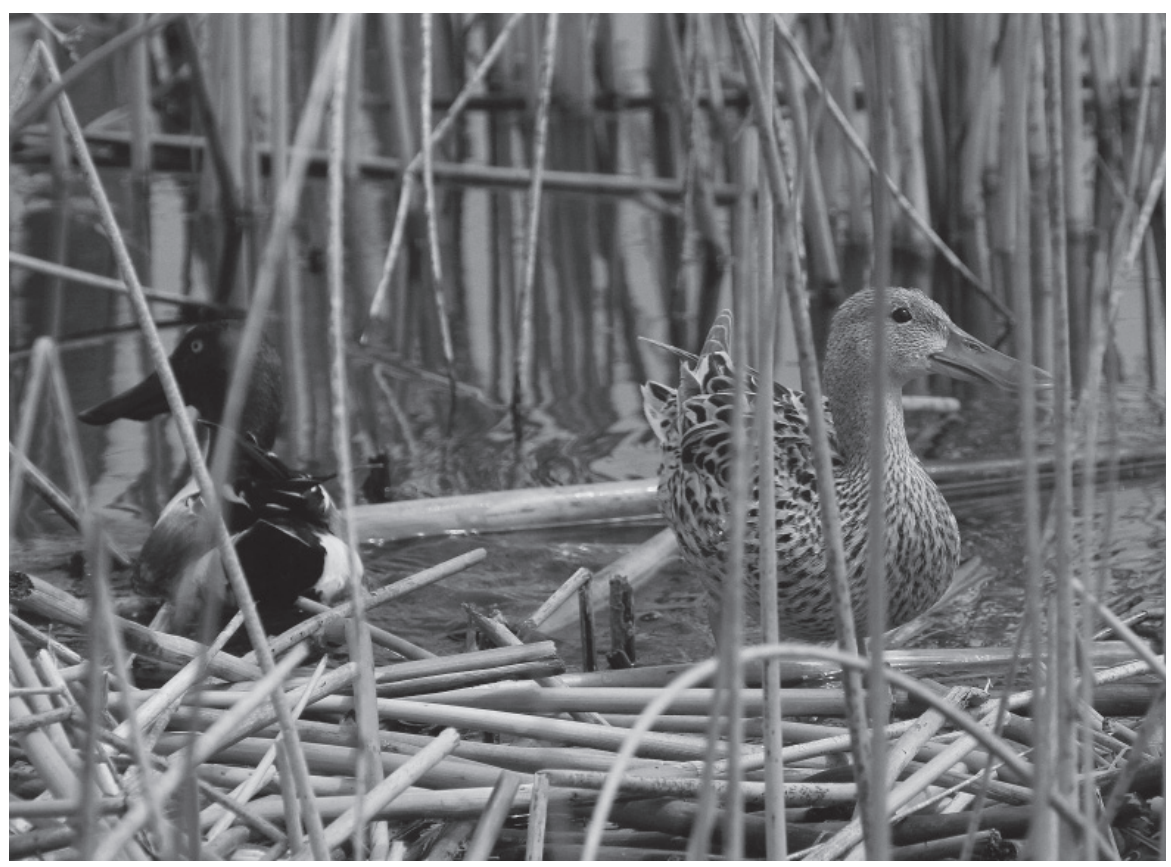

Northern shovelers

- Anne Brigham 